\title{
What Does Intercollegiate Athletics Do To or For Colleges AND UNIVERSITIES?
}

\author{
by
}

Malcolm Getz and John Siegfried

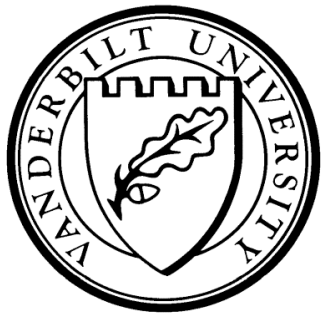

Working Paper No. 10-W05

May 2010

\section{DEPARTMENT OF ECONOMICS \\ VANDERBILT UNIVERSITY \\ NASHVILLE, TN 37235}

www.vanderbilt.edu/econ 
February 2010

Revised May 2010

\title{
What Does Intercollegiate Athletics Do To or For Colleges and Universities?
}

\author{
by \\ Malcolm Getz* \\ And \\ John Siegfried** \\ *Vanderbilt University \\ **American Economic Association, Vanderbilt University, and University of Adelaide, \\ South Australia ${ }^{1}$
}

Fielding high quality athletic teams that generate substantial revenues for colleges and universities by competing against rival universities is a peculiarly American phenomenon. Unlike many American innovations, virtually no other country in the world has copied it. Such uniqueness ought to provoke reflection about the role of big-time sports in the American academy (Clotfelter, Chapter 1, 2010).

One explanation for this sports-scholarship partnership is that inputs used in higher education complement those used in athletics. The primary input for both production processes is young adults. In the presence of diminishing marginal returns both to academic study and physical exercise, engaging in sports and study over a similar period might increase productivity. But why, then, would many universities partner with quasiprofessional sporting teams, but not with, say, landscape architects, construction firms, or, as former University of Chicago President Robert Hutchins once asked, racing stables? University students could plant shrubs, carry bricks, or ride horses just as easily as they can participate in commercialized athletic competitions against other universities, and all of these activities require intense physical exertion.

Roger Noll (1999) argues that universities field athletic teams to attract students who want to participate in organized sports. Many prospective students have played on

\footnotetext{
${ }^{1}$ The authors thank Charles Clotfelter, Brad Humphreys, Leo Kahane, Kevin Quinn, Stephen Schmanske, Peter Sloane, and Andrew Zimbalist for helpful comments on an earlier draft.
} 
organized youth teams, and have represented their high school on athletic teams. They enjoy uniforms, teammates, and trophies. This preference for participation can explain the prevalence of a wide array of athletic programs from the Ivy League, whose members field as many sports teams as any university in the U.S., to elite liberal arts colleges that play in the National Collegiate Athletic Association's Division III without athletic scholarships (although it's members do give admissions preferences to some athletes). Of course collegiate athletics were important in America when kids played sports on an empty lot with whoever showed up, wearing t-shirts and jeans. So, there must be more to the demand for college athletic competitions than just uniforms and trophies. And, while the desire to be part of a team can rationalize student demand for sporting opportunities in the form of intramurals and "club sports," it does not explain the high level of spending on coaches, recruiting, travel, and facilities, particularly for the large commercialized operations of Division I football, or men and women's intercollegiate basketball. The discussion below reviews available evidence on the returns to universities from supporting big-time televised college sports, including effects on government support, philanthropy, admissions, and on students themselves.

\section{Direct Effects on Institutional Revenue}

In light of the substantial ticket prices charged for big-time college sporting events such as football at the University of Michigan, men's basketball at Duke, or women's basketball at the University of Tennessee, a tempting explanation for the peculiar partnership is that universities sell sports entertainment services to the public to raise revenue that they then can reallocate to the (academic) mission of their institutions. Indeed, a 2006 survey found that 78 percent of Americans believe college athletics programs are profitable (Knight Commission on Intercollegiate Athletics, 2006). But reports by university administrators (Duderstadt, 2000), economists (Zimbalist, 1999), and even the NCAA itself (Osborne, 2004; NCAA, 2009), raise considerable doubt that revenues garnered by university athletic departments contribute much to supporting the academic enterprise financially.

In the first place, there seem to be relatively few Division I universities that actually earn net positive revenues from their football and basketball programs (Duderstadt, 2000). 
In 2007-08, for example, only 25 of the 119 Football Bowl Subdivision universities in the NCAA ran an athletic department surplus. Individually, a majority of football programs failed to cover their operating costs from 2004 to 2006 (Fulks, 2008). If capital costs and an allocation for general university overhead (e.g. administrative time, security costs, etc.) were included, the financial results would look even worse. This is partly the result of a zero-sum game that encompasses universities fielding Division I sports (Frank, 2004). It is also a function of the large variation in revenues earned by Division I athletic departments. The reliably more successful teams earn greater revenues, which can (but often do not) leave them with a net surplus. Athletic success is largely positional-what is valuable is winning the game, the league championship, or the national championship. Unfortunately, for every winner, there is a loser, for every league champion there is a doormat, and for every national champion, there are many more "also rans." If the teams that do not achieve positional success fail to garner anticipated revenues, they may be tempted to invest in improving their circumstances so that they can be more successful in the future. They may boost the salaries of coaches so as to attract what appear to be more successful team leaders, they may remodel or replace expensive physical facilities so that better players will be interested in playing for their university, and they may expand their game schedules geographically in order to appeal to recruits who have never ventured far beyond their own neighborhood. Such efforts cost money, which could and would generate success except that rival institutions are doing the same thing, and in the end, there can be only one winner of each game, only one league champion, and only one national champion.

Although colleges and universities have a built-in demand for athletic services from their alumni that helps them attract paying fans and television contracts, collegiate teams lack the controls imposed by professional leagues to avoid competitively spending themselves into poverty. This puts them in an incessant quest for athletic superiority that is collectively doomed to mediocrity and inevitably leads to the dissipation of revenues through aggressive rent seeking behavior (Frank, 2004). Indeed, the athletics arms race may be escalating, with large television revenues bringing ever greater focus on just a few premier teams. Coaches and athletic administrators earn salaries substantially above their best alternative pay, and stadium architects and construction firms gain business they would otherwise not receive. Even though the student stars that fill the enormous stadiums are not paid, there is usually little left from athletics profits to subsidize the academic missions of 
the colleges and universities the teams represent. Indeed, the flow of funds seems to move in the opposite direction. A 2010 report concluded that "more than $\$ 800$ million in student fees and university subsidies are propping up athletics programs at the nation's top sports colleges, including hundreds of millions in the richest conferences." (Gillium, Upton and Berkowitz, 2010). Indeed, the concentration of television revenues on post-season play and national champions may be molding a winner-take-all market with outsized rewards for the teams at the pinnacle, and losses for all the rest. In spring 2010, the NCAA expanded its men's basketball tournament to 68 teams as it signed a 14-year contract for television broadcast rights for $\$ 10.8$ billion. Rampant press speculation in 2010 suggests that there will be fewer, larger major college football conferences in the years ahead, perhaps only four super-conferences that will increase television revenues from conference football championships. (Thamel, 2010) With a larger reward at the pinnacle, the climb to the top will get steeper, yet more enticing. Nevertheless, if history is informative, the competition will be no more profitable for the colleges.

The lack of reported financial surpluses from commercial college and university athletics is partly a function of academe's unusual accounting practices. If a university is not at its maximum enrollment, the incremental cost of adding scholarship athletes is likely to be significantly less than the full-tuition scholarship that is reflected on the university's books as an accounting cost, because the athletes will fit into existing classes without hiring additional instructional staff, and will live in housing that may otherwise have stood vacant. Even if a recruited athlete did displace another student, the net average cost of losing that other student may be less than the cost of the athlete. Many students in the general student body receive scholarships and/or subsidized loans, while athletic departments typically provide extensive and expensive tutoring and other academic support to athletes that are not furnished to other students. Because an ordinary student who might replace a studentathlete may not pay the full tuition sticker price and likely consumes fewer academic support services, he or she would cost less than a scholarship athlete.

On the other hand, conventional university fund-accounting does not charge to athletics (or any other operating unit) the full depreciation cost of facilities, and some institutions do not charge any of the costs of scholarships for student- athletes to the athletic department. The true net effect of these various accounting quirks is unknown. Borland, 
Goff, and Pulsinelli's (1992) study of Western Kentucky University suggests that athletic department losses may be overstated by exaggerated costs, but, of course, their conclusion is based on the experience of only one university. On the revenue side, big-time athletics generates ticket sales, royalties on logos, and television contracts, usually shared among conference members. Yet, expenditures continuously expand to consume even more than the available revenue.

\section{$\underline{\text { Indirect Effects }}$}

If big-time collegiate athletics is not a direct financial bonanza to colleges and universities, why then, does the vast majority of America's leading universities spend large sums of money on coaches, facilities, and scholarships to field competitive teams in football, men's and women's basketball, and often intercollegiate ice hockey (in the north) or baseball (in the south)? The conventional answer to this question is "indirect benefits." For example, as a form of advertising, public relations, and consumption (entertainment), intercollegiate athletics may increase financial donations to a university from former athletes, from sports fans who are not alumni, from alumni who are not necessarily sports fans, or from people who are not directly connected to the institution. Athletic success may attract more students with academic talent, enhancing a university's academic prestige. Success in athletics may be interpreted (correctly or not) as a signal of excellence in all pursuits, including academic, and thus attract the attention of those who fancy themselves as people associated with success. This view is summed up succinctly by David Schmidly, president of the University of New Mexico, who said: "One of the most effective ways to market your university nationally is to have a really quality athletic program. It helps recruit faculty, students, and donors. It helps with the image of the whole university." (Zengerle, 2010)

\section{$\underline{\text { Indirect Effects on Government Support }}$}

At public institutions, athletic success might attract larger university appropriations from state legislators concerned more with the perception of the university by the majority of voters among their constituents who do not hold a college degree than by the minority in 
their districts who have earned a baccalaureate degree. Allen (1999), for example, reports that the University of Connecticut managed to secure an additional billion dollars from its state legislature by capitalizing on the success of its men's and women's basketball teams in 1999, when the men won the national championship. More systematic evidence supports Allen's anecdote. Using data on 570 public universities, Humphreys found that those fielding Division I football teams receive about eight percent more from their state legislature than otherwise comparable universities that do not participate in Division I football. Participation seems to be what matters. Success is less important. State subsidies appear to be no greater for universities with top-twenty or bowl-participating football teams.

Government may also be interested in increases in sales tax revenue emanating from taxable sales of tickets to large scale college events. Local officials may expect that increased ticket sales to the large crowds add more to their revenues than local government lays out for the extra police and ambulance services required by the crowds. State officials might value the visitors attracted to the state by popular sporting events. Coates and Depken (2008) use daily sales tax receipts for cities in Texas to investigate whether sales tax revenues rise or fall on game days. They find that for a typical highly attended game, local sales tax revenues fall, suggesting the local residents and visitors spend less on the congested game days than crowded-out locals would spend on a non-game day. However, in-conference games with in-state rivals seem to generate sufficiently more sales than the average game day to about offset the usual dampening effect of game day congestion on local sales. Rees and Schnepel (2009) report evidence that crime is higher on game days. We know of no direct measure of the inconvenience to locals of the extra traffic and noise created by popular college sporting events. Public officials' enthusiasm for college sports appears to be motivated by something other than fiscal effects.

\section{$\underline{\text { Indirect Effects on Donations }}$}

There are over a dozen empirical studies of the effects of participation and success in intercollegiate athletics on private donations to colleges and universities. They vary substantially in quality. Early ones failed to employ adequate controls and used small and sometimes inappropriate samples or suspect statistical techniques (e.g. step-wise regression), but the pioneers deserve recognition for directing attention to this question. 
The studies differ in important ways and draw divergent conclusions that do not yield simple, general findings. Some examine Division I universities with expensive sports programs, while others investigate Division III (mostly liberal arts) colleges with no athletic scholarships. Some look only at donations made by former athletes, some examine donations by all alumni, and some investigate donations made by people with no obvious association with the university. Some studies focus on donations restricted to use for athletics, some look at donations that can be used for anything except athletics, and some consider unrestricted donations. Some compare contributions to a single university as its athletic fortunes wax and wane. Others are cross-sectional, comparing donations to different institutions at a point in time, while trying to hold constant other differences among them. More recent work has employed panel data to exploit variation in sports participation and success across both institutions and over time. Finally, some studies focus on how intercollegiate sports affects the fraction of potential givers (usually alumni) who donate, while others correlate sports participation and success with the dollar value of the donations received.

One hundred twenty-four American colleges and universities, about 13 percent, changed the level of their intercollegiate athletics participation between 1991 and 1999 (Sandy and Sloan, 2004). Among them, 109 went up and 15 went down in classification. Harrison, Mitchell, and Peterson (1995) explore the effect of an institution's participation in Division I intercollegiate sports per se on alumni donations. Comparing 18 heterogeneous colleges and universities, ranging from Berea and Baylor Medical College to the Universities of Chicago and Georgia, they observed no correlation between Division I sports status and alumni donations. This may be the most important empirical result we review, because choice of level of play is not a zero-sum game. Teams at each level win about 50 percent of their contests. On average, moving to a higher level of play adds costs without changing the average winning percentage.

At the level of individual donors, Clotfelter (2003), Monks (2003), and Wunnava and Lauze (2001) all find that alumni who participated in intercollegiate athletics when they were students donate more than alumni who never saw the inside of a locker room. More recently, Holmes, Meditz and Sommers (2008), studying 22,000 Middlebury College alumni, found that former athletes are 22 percent more likely to donate than non-athletes, 
and, on average, former athletes donate about 20 percent more than non-athletes. Meer and Rosen (2008) find that at one university, alumni male athletes who had played on national championship teams as undergraduates contributed about seven percent more per year (with the exception of football and basketball players); there was no similar effect for women. Only Shulman and Bowen (2001) found contrary evidence, reporting systematically lower unrestricted donations by former athletes than non-athletes. Because Shulman and Bowen analyze data on 111,000 individual graduates of 30 colleges and universities over 40 years, however, their evidence is important (Siegfried and Getz, 2002). Consequently, it seems pre-mature to draw a conclusion about whether athletic participation by individuals alters the level of future donations a university might expect to receive from them.

Although the first published study of the effect of athletic success on donations (Sigelman and Carter, 1979) reported no relation between total alumni giving (to both the athletic department and to other parts of their alma mater), three other early cross-section studies [Brooker and Klastorin (1981), Sigelman and Bookheimer (1983), and Coughlin and Erekson (1984)], did observe higher contributions associated with athletic success. These early studies used limited data sets and did not adequately control for other important determinants of alumni contributions.

Donation studies in the 1990s employed better data and statistical techniques. McCormick and Tinsley (1990) and Grimes and Chressanthis (1994) switched the focus from cross-section to time-series analysis, studying donations to Clemson and Mississippi State Universities, respectively, as the success of their intercollegiate football teams waxed and waned. Both found a positive correlation between athletic success and general giving. McCormick and Tinsley found that the success of the Clemson football team initially increased athletic contributions. They also observed that, over time, Clemson's general endowment increased when athletic contributions rose. Later, Goff (2000) looked at the effect of football success on fund raising at Georgia Tech, which shared the national football title in 1990, and Northwestern, after its 1995 Rose Bowl appearance, a relatively infrequent event for the Wildcats. He found no evidence that Georgia Tech's football success improved general fund raising at the university, but did observe a significant increase in Northwestern's endowment immediately after its unprecedented football achievements. The President of Northwestern, however, indicated that a simultaneous 
financial reorganization probably created the appearance of financial returns to the football success.

Baade and Sundberg (1996) were first to use panel data with many observations, a giant leap forward in estimation procedures. They correlated general giving information collected from the Council for Aid to Education with athletic success for 142 universities and 167 liberal arts colleges from 1973 to 1990, capitalizing on both cross-section and timeseries variation, while controlling for differences in other characteristics of the institutions and their students. They considered two dimensions of athletic success-the football and men's basketball teams' regular season winning percentages, and post-season bowl or tournament participation by each team. Regular season winning percentage was unrelated to donations for both private and public universities, but for private universities, a football bowl appearance was associated with an increase in general alumni contributions, boosting the average contribution by about 50 percent. It is possible, however, that the expansion of bowl games in the decades since Baade and Sundberg completed their study might have diminished the donations effect of bowl appearances. Basketball tournament participation did not affect donations. For state universities, whose external fund raising is generally less than that of privates, playing in a post-season football bowl game or the men's basketball tournament were both associated with a statistically significant increase in contributions of about 40 percent. For liberal arts colleges, which do not go to bowl games or the NCAA Division I basketball tournament, the average football regular-season winning percentage was statistically significantly related to greater contributions, but the size of the effect was trivial. Basketball success does not seem to matter for donations to liberal arts colleges either.

Following Baade and Sundberg, Rhoads and Gerking (2000) analyzed panel data on donations collected by the Council for Aid to Education for 87 Division I universities for the decade starting in 1986-87. They used a fixed effects model that relies primarily on changes over time for individual institutions. While they examined only the effects of success in post-season bowl games and basketball tournament appearances, they did consider contributions made by alumni separately from contributions made by others. They found that winning a football bowl game stimulates contributions by alumni, but is unrelated to contributions from others. Basketball tournament victories do not seem to 
affect donations of either group. A football bowl victory is associated with a seven percent increase in alumni donations.

The largest sample of individuals in which a correlation between generosity and athletic success has been explored is the Andrew W. Mellon Foundation's College and Beyond database containing about 75 percent of all graduates from the entering classes of 1951, 1976, and 1989 at 30 selective colleges and universities, including eight that play football in Division I-A, the Football Bowl Subdivision (Shulman and Bowen, 2001). Those data reveal no evidence that winning in high-profile sports promotes alumni giving. There is no connection between football winning percentages and the level of general contributions from donors who did not personally participate in intercollegiate athletics. Contribution rates from former athletes do seem to rise with subsequent athletic fortunes of their schools, but since the 1970s former athletes have been less generous alumni than nonathletes, and they constitute a small proportion of total alumni at most universities, although they are a larger fraction of selective liberal arts college graduates. Survey responses indicated that graduates who made the largest contributions favor a de-emphasis of sports at their alma maters.

In a more focused panel analysis of giving by 15,351 alumni of 15 private institutions from the College and Beyond data for the decade starting in 1989, Turner, Meserve, and Bowen (2001), found no effect of football winning on the proportion of alumni who contributed to either a university's general fund or to the athletics department for the eight Division I universities in the sample above plus one with just basketball. The value of contributions actually declined when the football team was more successful.

Litan, Orszag, and Orszag (2003) studied the effects of football success for the NCAA. They had access to confidential data that are not available to other scholars. Using a fixed effects model, they found no statistically significant relationships between football winning percentages and either total alumni contributions or donations restricted to football programs. Tucker (2004) related the percentage of undergraduate alumni who gave money to their school during the 1999-2000 and 2000-01 academic years to average winning percentages, post-season bowl and tournament appearances, and final Associated Press (AP) rankings for both football and men's basketball at 78 Division I universities. He found no 
association between basketball success and the fraction of alumni donating, but did observe significant positive correlations for football achievements. A 10 percent increase in football winning percentage (about one win per year) was predicted to increase the proportion of alumni who make contributions by about one percentage point. One additional bowl appearance or appearance in the Top-20 final AP football poll over a six-year period also was predicted to increase the giving rate by about one percentage point.

Humphreys and Mondello (2007) used a comprehensive panel data set for 320 colleges and universities drawn from the Integrated Postsecondary Education Data System for the period 1976-1996, a previously untapped source for donation studies. Their data include giving by alumni, foundations, corporations, and others. They studied both restricted and unrestricted donations, although the restricted donations were not necessarily restricted to athletics. They found no increase in unrestricted donations as a result of any measure of success of either the football or men's basketball teams. Restricted giving appeared to rise at both public and private universities in response to success of the basketball team, and at publics when the football team is invited to a bowl game.

In sum, the more recent studies (by Baade and Sundberg; Shulman and Bowen, Turner; Meserve, and Bowen; Litan, Orszag, and Orszag; Tucker; and Humphreys and Mondello) use a variety of data sources, consider different donors, separate gifts into those restricted to athletics and those donated for general purposes, and rely primarily on the variation in giving over time for individual institutions in samples of more than one university. These studies do an adequate job of controlling for other influences on contributions. Some find no effect of athletic success, while others find a modest effect, usually on restricted giving. Participation in post-season play by the football team seems most likely to function like advertising for the institutions, increasing awareness of the university, and perhaps allowing the university to capture a larger share of the donations market. This evidence, however, is not sufficient to show that the financial subsidies most universities provide to their athletics programs reap rewards sufficient to improve the institutions' overall financial condition, because for every winner, there is a loser. The average gain is nil, but the subsidies spent in pursuit of the gain are incurred by all teams. 
The analysis of giving patterns using regression analysis tends to focus on the number of givers and average level of donations. In dollar terms, however, the behavior of a few of the largest donors may dominate the averages. T. Boone Pickens' gift of $\$ 160$ million to Oklahoma State's athletic program in 2006 topped Ralph Engelstadt's \$100 million gift to North Dakota's ice hockey program in 1998 as the largest on record. (Associated Press, 2006) A university may sensibly focus on total dollars. A statistical analysis that accounts for only occasionally observed large gifts requires use of different methods and larger data sets than have been available so far.

The analysis of benefits should be balanced against an assessment of costs. If athletic success increases donations, a next step in the analysis might be to estimate the cost of increasing athletic success. How much more spending is associated with increased winning and how is more spending most effectively deployed? Of course, if all of the competitors increase spending in proportion, the likely effect on winning will be nil. The analysis might then ask how often institutions in a given competitive group increase spending that is not matched immediately by their rivals? Showing that winning stimulates more giving isn't sufficient to conclude that devoting more resources to athletics will pay. The literature on college sports offers little guidance on how to produce winners.

\section{The Opportunity Cost of Increased Donations}

What, then, should we conclude from these results? Although the evidence is scant, suppose contributions to colleges and universities do increase when the institutions enjoy intercollegiate athletics success. Is this a "good thing?"

Evidence correlating university donations to athletic success reveals only half of the effects of a resource reallocation. What is the opportunity cost of additional donations received by an institution that wins a bowl game or the national championship in football or basketball? Would the funds otherwise have been donated to another college or university? If so, by how much does the reallocation of donations among academic institutions on the basis of their athletic success increase welfare? Or is it possible that the donations could have alternatively constituted more valuable incremental contributions to other charitable 
organizations, e.g., the Red Cross, American Cancer Society, or a local repertory theater group?

In whose view might the donations' next best use have been more valuable? Presumably, donors value their contributions directed as they prefer more than their next best alternative. But are the donors fully informed, or is there a "winner's myopia?" If donors knew that winning is partly random, would they still value gifts to winners? If winning is mostly random but donors attribute wins to deeper forces, would the pattern of giving have as much social value as gifts made on other grounds? Is society better off if donations go to the athletic department of a university with winning intercollegiate athletic teams, boosting salaries of the coaching staff or building plush skyboxes, with no clear effect on either winning or on improved academic performance of the institution? Or would society be better off with the donations directed to the use they would find if intercollegiate athletics did not exist, or was not hyped to the degree it is? At the very least, the opportunity cost of the donations is surely not zero; thus, the net social value of donations stimulated by athletic success is undoubtedly less than their gross value to the university that receives them.

Alternatively, the donated funds might have been spent on the donors' consumption, or been added to savings. Is a diversion of consumption or savings to collegiate donations stimulated by high-profile athletic participation or success desirable? These important questions are never asked when the fund raising prowess of successful athletic teams is proudly reported. It seems to us impossible to intelligently judge the desirability of additional contributions that may be stimulated by athletic success without knowing the source and opportunity cost of the money.

\section{$\underline{\text { Indirect Effects on Applications and Enrollment }}$}

As a form of advertising and public relations, or as the consumption of entertainment services, intercollegiate athletics may attract students, thereby substituting for alternative recruitment expenditures. Simply having Division I sports teams seems to matter more than success of the teams. Describing a 15-year three billion dollar agreement with ESPN to televise Southeastern Conference intercollegiate athletics, Wolverton (2009) 
reported that the universities "hope the exposure will help them attract students who would otherwise not have considered their universities."

There is systematic empirical evidence bearing on the question. Sandy and Sloane (2004) found that institutions with Division I sports programs attract more applications and enroll students with higher average SAT scores than similar institutions that do not participate in Division 1 sports. McCormick and Tinsley (1987) discovered the same thing when they distinguished those 63 universities in one of the six "big-time" athletic conferences (and a few independents) from other colleges and universities. Osborne (2004) found that students actually are willing to pay for big-time athletic programs, and, indeed, do so, as those universities with big-time athletic programs charge higher tuition and fees, ceteris paribus. However, there is important contradictory evidence about the attractiveness of big-time sports to students, at least for more academically oriented colleges and universities. Looking at the huge College and Beyond sample of alumni from 30 selective colleges and universities, Shulman and Bowen (2001) found compelling evidence that average graduates of universities with Division I sports claim to prefer less emphasis on intercollegiate athletics.

The choice of level of competition (Division I, II, or III) and perhaps the decision of which conference to join is less susceptible to the zero-sum game problem than the decision whether to accelerate expenditures in an effort to be more competitive at whatever level of play has been selected. While Division I is much more costly than Division II, which, in turn, is more expensive than Division III, the decision to move up in level does not mean that another institution necessarily moves down, and revenues, as well as costs rise as one moves to a more competitive level of play.

Nevertheless, winning also may attract the attention of prospective students. It has been reported (USA Today, April 3, 1985) that North Carolina State enjoyed a 40 percent rise in applications after winning the NCAA men's basketball championship in 1983 with charismatic coach Jim Valvano, and that Boston College received close to 4,000 more applications in 1985 than in 1984, after its highly publicized football season during which Doug Flutie beat favored University of Miami with a long last-play pass, and won the Heisman Trophy. 
Systematic evidence concerning the effect of success at Division I sports in attracting the interest of prospective students is ambiguous, but the better studies suggest that winning or participating in post-season competition does not generate much additional student interest. Two types of outcomes have been examined - the size of the applicant pool, and the academic credentials of the enrolled class. While the academic credentials of enrolled students would seem to be the objective, a larger applicant pool could permit an institution to enroll fewer students requiring financial assistance, or to choose a more diversified student body, and thus be a goal in and of itself. A larger applicant pool reduces the admission rate and boosts national rankings even when there is no change in the students who enroll because the ratio of enrolled students to applicants is an element of many college ranking systems.

Applying a fixed-effects model to panel data on universities in the six big-time football leagues, Murphy and Trandel (1994) found that football conference winning percentage is correlated with the number of undergraduate applications received the following year. While statistically significant, the size of the effect is modest. If a school increases its winning percentage from half to three-quarters of its games, for example, the application pool is predicted to increase by only 1.3 percent.

Toma and Cross (1998) looked explicitly at the effect of winning a national football championship or men's basketball championship during the period 1979 through 1992 on applications received the year after the championship. They contrasted changes in applications experienced by championship universities to contemporaneous changes at five other colleges and universities that each champion identified as its competitors for students. For football, 10 of the 16 champions in the sample enjoyed a subsequent boost in applications of at least a few percentage points more than the average of their peer institutions. In basketball there was only one anomalous spike in admissions applications following a championship season, after Michigan won the 1989 men's championship. Applications appeared to grow primarily at more academically selective institutions that enjoyed athletic success. 
McEvoy (2005) also found that increased winning in football boosted undergraduate applications, but showed no effect for men's or women's basketball. Schools whose football in-conference winning record increased by at least three wins per year realized a subsequent average gain of 6.1 percent in undergraduate applicants. Schools with no change in their in-conference football winning record experienced virtually no change in their application pool. Zimbalist (1999) also found a tendency for intercollegiate athletic success to boost applications.

Asking whether the increased applicant pool made any difference for the college, McCormick and Tinsley (1987) were among the first to relate intercollegiate athletics success to freshmen academic credentials. They found that universities with a winning trend in football from 1971 through 1984 enjoyed higher average freshmen SAT scores from 1981 to 1984 . Tucker and Amato (1993) observed a greater increase in the average freshmen SAT score at universities with a higher average final Top-20 football AP rating during the 1980s. An increase of three places in the AP ranks over the decade was predicted to raise SAT scores by three percent. Again, success in basketball did not appear to matter. Bremmer and Kesselring (1993) related changes in SAT scores for the freshmen class to appearances in football bowl games and the NCAA basketball tournament over a nine-year period, finding no evidence that athletic success improves the academic credentials of the freshman class. Zimbalist (1999) also found no correlation between athletic success and SAT scores.

Using an unusually comprehensive data set, including proprietary NCAA data, Litan, Orszag, and Orszag (2003) reported no effect of football winning percentages on average freshmen SAT score. Mixon, Trevino and Minto (2004) found that institutions with better big-time football winning percentages during the 1990s landed a 2001 freshman class with higher SAT scores, ceteris paribus. Again, however, the effect was small. Improving from a 3-9 record to 9-3, a dramatic change, was predicted to increase the average freshmen SAT score by only four percent. Goff (2000) found that post-season achievements attract more applications, but only at academically select institutions.

Tucker (2005) looked at the period after the Bowl Championship Series began to generate more hype for post-season football. He first set a baseline for comparison. Like 
Bremmer and Kesserling, he found no measures of football success related to freshmen SAT scores before 1996. When he repeated the analysis for 1996 to 2002, however, he found that football winning percentage, AP rank, and bowl appearances were associated with higher SAT scores. A 50-percentage point increase in winning (e.g., from a 3-9 record to 9-3) was associated with a six percent increase in SAT scores. One extra bowl appearance over six years was related to a one percent increase in SAT scores. Examining the effect of men's basketball on a school's academic credentials, Smith (2008) found that neither membership in a power basketball conference, nor success in basketball (winning percentage, appearing in the NCAA basketball tournament, or making the Final Four of the tournament) were associated with stronger student academic credentials. If there is an advertising effect of intercollegiate sports, it apparently does not operate through basketball.

The most comprehensive and careful study of the advertising effects of intercollegiate sports is by Pope and Pope (2009), using data from 1983 through 2000 for all 330 NCAA Division I universities with football or basketball programs. To isolate the influence of athletic success in attracting students, they controlled for unobserved effects due to each school, trends in each school's admissions, effects on admissions that apply similarly to all schools in a given year, and for other attributes of the institutions that might influence admissions, including the cost of attendance and real income in the state.

Basketball success was measured by participation in the NCAA tournament, the Sweet 16, the Final Four, and winning the National Championship. Football success was based on the final AP ranking, and National Champion. They employed zero, one, and two-year lags.

In contrast to most other studies, Pope and Pope report significant effects for basketball that persist over two years, particularly for private universities. Appearing in the NCAA tournament boosts applications by one percent, making the "Sweet 16" bumps the gain to three percent, with a 4-5 percent gain for the Final Four, and 7-8 percent for the Champion. The biggest effect is in the following year with little effect remaining after three years. For football, a Top-20 finish adds 2.5 percent to applications and a Championship adds 7-8 percent, with a big effect in the immediate year and little effect after one year. Private institutions gain more than publics from success in basketball, with less difference for football. 
Pope and Pope also estimate whether universities expand their enrollments following athletic success. Success in football is associated with increased enrollment at public universities but success in basketball shows no enrollment effect. In contrast to Osborne (2004), Pope and Pope find little evidence that athletic success allows universities to raise tuition.

To consider the effect of athletic success on academic credentials, Pope and Pope estimated how athletic success affects the number of students sending SAT scores to various universities. Although students with lower SAT scores appear to be more sensitive to athletic success, students with all levels of SAT scores send more scores to universities that have enjoyed recent athletic success. The influence of winning on applications, enrollment, and SAT scores, however, is not sufficient to show that universities with bigtime athletics programs come out ahead for their effort. For every winner that gains a positive effect, there is an offsetting effect for a loser. The winning and losing effects average to zero, but the costs are incurred by all.

Athletics also plays a role in admissions, but the effect is little studied. Anecdotal evidence suggests that fielding intercollegiate sports teams can draw more students from under-represented groups. For example, Shenandoah University revived its football program in 2000 to attract more males to its then female-dominated student body. (Pennington, 2006) In contrast, Stevens Institute of Technology introduced women's athletics to attract more females. In 2004, 43 percent of Stevens' athletes were women while the student body was only 24 percent female. (Wolverton, 2006) Sports opportunities may draw students from different demographic groups that enrich college life for all students.

Even the best studies of enrollment effects are limited to documenting how relatively small changes in athletic performance effect applications and enrollment. They provide little guidance about the consequences of substantial change. Suppose what is now college football and basketball were no longer supported by institutions of higher education, but instead shifted to professional player development systems operated by the premier leagues. What would happen to enrollment in higher education? Would it decline? Would the few dozen universities with teams now featured regularly on television experience 
declining enrollment? Would the enrollment level and possible shifts among colleges and universities lower the general welfare of the population? Without the responsibility of intercollegiate athletics competition, Division I universities could redirect funds currently used to subsidize athletics to other uses, such as recruiting students directly, or enhancing their academic programs in ways that might yield better outcomes for the institutions and the students who attend them. Existing studies do not address such larger possibilities.

\section{The Opportunity Cost of Indirect Effects on Applications and Enrollment}

Evidence seems to support the notion that Division I intercollegiate athletics provides consumption benefits for students, thereby attracting applications. There may, however, be an opportunity cost of this consumption if students spend relatively more time enjoying the success of their team than studying. So far, however, there seems to be no reason to worry about this, as Rishe (2003) found that average institutional graduation rates are unrelated to football success. This is no surprise, as there are undoubtedly many important determinants of institutional graduation rates other than distractions from study caused by enthusiastic student supporters of athletic teams.

There is some evidence that the presence and success of intercollegiate athletics at colleges and universities may increase the applicant pool, and possibly may improve the academic credentials of the student body of institutions that win national championships. But for every institution that wins a national championship, there are hundreds that do not. Although no one has devised a way to test the hypothesis that the presence of intercollegiate athletics increases the overall proportion of high school graduates who attend college, there is no evidence to suggest that this might even be possible beyond the important but small effect of increasing the prospects of the athletes themselves attending college.

National intercollegiate athletics championships may alter the mix of institutions to which college prospects apply, and may affect the yield (the fraction of admitted students who enroll) on admitted applicants experienced by various institutions. In other words, sports success may rearrange students among colleges and universities. But, is this a "good thing?" Is learning improved if prospective students decide which universities should receive their applications and which university they should attend from among those 
that admit them based on the knowledge of different institutions they gain by watching the hype surrounding successful intercollegiate athletic teams on television? Are the studentuniversity matches better or worse if sports success reshuffles students?

If, ultimately, the athletic success of football and basketball teams is decided in recruiting battles to sign high school athletes, as many successful coaches claim, are we comfortable with decisions about which college or university some non-athlete students will attend being influenced by which institution can hire a coach who can best persuade a 17 year old star high school athlete that he or she will be best served playing for that coach? It seems a peculiar way to choose a college. For more conventional criteria for college choice, see Getz (2007).

One might challenge the argument that college athletics is a zero sum game by noting that colleges engage in arms races in many areas, including academic disciplines. Colleges compete to build more highly ranked programs like physics, English, and economics. These competitions bid up the salaries of visible faculty "stars," diminish the amount of contact research-active faculty must "endure" with undergraduates, and redirect financial aid to merit scholarships for academically superior affluent students. Positional competition causes a misallocation of resources. Athletics differs, however, in that the athletic arms race draws resources away from the academic missions of universities, while academic arms races likely promote at least some dimensions of academic achievement that were contemplated when the institutions' charters were written. The arms race in athletics is most evident in the bowl-active football and leading basketball programs where the resource commitments are substantial, and the relationship to academic goals is minimal.

\section{$\underline{\text { Effects on Students }}$}

The evidence above suggests that college sport is a zero-sum game among universities. However, from other points of view the competition could spawn positive or negative sums. One case for a negative involves NCAA rules against paying players. Payments-in-kind of tuition plus room and board offered as athletic scholarships may be less valuable than the cash equivalent that at least some college athletes might receive if professional training-level-athletic-competition were organized by competitive entities with 
free entry or by the corresponding professional leagues themselves, a la minor league baseball (Zimbalist, 1999). Moreover, press accounts of college athletes who have lived in enclaves isolated from the rest of the student body, who could not read, and who took courses only open to athletes, suggest that some colleges do not even deliver on the promise of a college education (Rather, 1985). Recent changes in NCAA policies now require that student-athletes be able to read before they enroll in college, that coaches be rewarded in part for the academic as well as athletic performance of their charges, and that athletes at least attend class (Brand, 2009). The worst abuses may be over. While the NCAA imposes sanctions on universities that violate its rules, such scandals may also have adverse effects on donations, applications and enrollments. Grimes and Chressanthis (1994), for example, show a decline in alumni giving after the NCAA imposed penalties on the football program at Mississippi State University. Goff (2000) finds a \$31 million annual decline in donations and a seven percent decline in the three-year average number of applications received after the NCAA closed Southern Methodist University's football program (the so-called “death penalty) in 1987 and 1988 after repeated rules violations. Zimbalist (1999), however, argues that the NCAA's enforcement process is largely a paper tiger.

On the other hand, because athletics heightens human performance, collegiate competition could be a positive-sum game. Plato saw athletic training as a complement to intellectual development. Modern psychology shows that gains in the vascular system from exercise stimulate neural activity at all ages (Reynolds, 2009). As a consequence, athletic participation correlates with other kinds of success. Long and Caudill (1991) estimate that athletes earn about four percent more than non-athletes approximately ten years after graduation, controlling for other personal characteristics. Using the College and Beyond data, Shulman and Bowen (2001, p. 95) similarly find that athletes enjoy higher lifetime incomes compared with non-athletes, ceteris paribus. The premium earned by athletes, however, is apparent only among those who pursue careers in financial services, a sector differentially favored by former athletes. Moreover, there is evidence that questions whether sports actually teaches skills that improve earnings, namely the fact that earnings are not related to the number of years former athletes played (Shulman and Bowen, 2001). And, the evidence contradicts the popular hypothesis that sports helps to develop leaders. There is no greater proportion of future CEOs from among former athletes than from among non- 
athletes in the College and Beyond sample (Bowen and Shulman). The connection between sport and lifetime performance is complicated.

One link is from fitness to level of play. Students can pursue fitness without participating in intercollegiate competition. Many who participate in competition do so at the intramural and club level. The level of play that involves paid coaches typically requires a higher degree of effort and physical performance. Those collegiate sports that offer paths to professional athletic careers are likely to stimulate the highest levels of physical, mental, and emotional performance. We don't know what dimensions of athletic participation contribute to lifetime performance. Moreover, intense athletic competition generates injuries that are particularly severe in football. The effect of big-time college revenue sports on lifetime fitness could conceivably be negative.

The link from athletics to academic performance is complex. The direct evidence from Shulman and Bowen (2001, p. 67) is that athletes earn lower grades than their nonathlete colleagues, even after controlling for their lower average high school grades and standard test scores. This finding is consistent with anecdotal evidence that many athletes are less serious students or make time commitments to athletics that undermine academic performance. In a study of grades at Penn State, Fizel and Smaby (2004) find that the lower grades earned by athletes are limited to a few sports like football, men's fencing, and women's field hockey, while grades of athletes in some other sports (e.g. women's swimming) are above average.

A different perspective is offered by the concept of stereotype threat. Dee (2009) compares the performance of athletes to non-athletes on an academic test at Swarthmore College. Before taking the test, half of the subjects got a verbal cue that evokes an image of athletics, the other half got a non-athletic cue. The athletes who got the non-athletic cue performed the same as non-athletes who got either cue. However, athletes who were reminded of athletics by the cue performed below both the other athletes and non-athletes. Apparently, participation in athletics builds a psychological frame that reduces measured academic performance. It would be interesting to learn whether the stereotype threat differs by gender, by sport, by type of college, and level of competition. Fizel and Smaby's (2004) results suggest the possibility of differences by sport. 
Another view of the link from athletics to academic performance considers graduation rates. Long and Caudill (1991) found a four percent higher rate of graduation for athletes, ceteris paribus. Amato et. al (1996) correlated graduation rates for football players with attributes of their college. They found post-season appearances by Division I universities were associated with lower graduation rates, suggesting lower academic emphasis at the highest levels of play. In a follow-up study, Amato et al. (2001) found that evolving NCAA rules apparently have eliminated the negative effect of post-season play on graduation rates. Importantly, they find much higher graduation rates for football players on campuses where graduation rates are higher for all students. Shulman and Bowen (2001, p. 61) also observed higher graduation rates for athletes (particularly for participants in lowprofile sports) but with non-athletes closing the gap more recently. Shulman and Bowen have the advantage of using information about individual students (rather than college averages) in estimating relationships. In the time since these studies were conducted, the NCAA has adopted rules that reward athletic programs that achieve higher levels of academic performance by athletes. As a consequence, graduation rates by athletes are likely to continue to increase. In addition, the higher level of financial aid received by scholarship athletes is likely to increase graduation rates by reducing attrition caused by financial problems.

Because students affect the performance of their peers, athletes may affect the learning of other students. Sacerdote (2001), Zimmerman (2003), and others took advantage of colleges that randomly assign students to dormitory rooms to demonstrate that residential peers influence academic performance. The evidence on athletic stereotype threats suggests hypotheses about the influence of athletes on the academic and social behaviors of roommates and other students. Shulman and Bowen (2001, p. 41) make clear that athletes have a significant advantage in admission even at academically selective colleges. On average, they have much lower standardized test scores than their peers, a gap that has grown over time and is largest in revenue sports. Consequently, athletes may be less attractive as academic peers both because of their weaker academic backgrounds and because they earn even lower grades than predicted on the basis of those weaker admissions credentials. 
Swarthmore chose to eliminate football, along with two other sports in 2001, primarily to limit the number of admission slots with an athletic nod to 10 to 15 percent of the class (Suggs, 2000). With an enrollment of only 1,400, including about 700 men, Swarthmore found that about ten percent of entering males would need to be recruited as football players to field a successful team. They seem to have decided that the football culture, the lower academic performance of recruited players, and the likely peer effects made the cost too high.

Another link is from athletics to personal satisfaction. It seems likely that athletes have goals in addition to income. Performing before a crowd of thousands of enthusiasts may offer its own satisfactions. Many athletes value the camaraderie that comes from being part of a team. The higher level of giving by athletes than non-athletes at Middlebury College (Holmes, et al., 2008) may reflect the sense of identity athletes achieve from participation, but the effect may be idiosyncratic to particular sports at some colleges.

Athletic performance may be an end in itself. Running faster, leaping higher, and lifting more may lead to satisfaction not measured by income. Winning times for track and swimming events and winning distances for field events have steadily improved over a long time. The trend is apparent for both men and women. Similar trends appear in winning Olympic performances. Performance may improve for many reasons, among them higher levels of spending on college athletics. Advances may result from better techniques, coaching, and selectivity as more children explore athletics, or may result from better facilities, year-round training, and higher rewards from national and international competition. Long-term trends in performance in team sports are more difficult to document but in many sports the level of athleticism and skill seems to increase over time.

The social value of sustained improvement in athletic performance by the most successful is difficult to determine. Surprisingly, the dramatic increase in childhood and adult obesity has occurred simultaneously with continued improvement in the performance of athletic elites. The biggest rewards and primary emphasis may arise because of spectator values in revenue sports rather than the direct value of participation. 
Athletics builds a sense of community that transcends the participants. The trustees of many universities seem to value intercollegiate athletic competition as an end in itself (Clotfelter, 2010). Perhaps the big-time sports enterprise reflects the personal utility these individuals enjoy. The experience of spectators may create bonds that extend to a substantial number of students, staff, and faculty, including many alumni, and fans from the local area. A college that seeks to be more than the sum of its parts may promote its mascot, its colors, and its athletic rituals as a way of drawing its many constituencies together. In this way, intercollegiate athletics enhances the value of a university's brand, and consequently the value of sweatshirts, license plates, and coffee cups that promote the brand. In 2009 Georgia State University, for example, decided to add a $\$ 170$ per year charge to its students to finance a new Division II football program to create a collective identity for the 97 year old school (Tierney, 2009). In an era when female enrollments are well over half of many student bodies, the male dominated sport may have extra appeal.

\section{Conclusion}

A lot of anecdotes and marketing hype are devoted to the prospect that winning university sports teams stimulate private donations to the successful schools. Systematic empirical evidence generally supports the anecdotes, although the effects appear to be small, and result primarily from the appearance of football teams in post-season bowl games. There are similar stories of individual universities attracting more applications following athletic achievements, although in this case, the empirical evidence is equivocal, and there appears to be little effect on the academic credentials of classes enrolled subsequent to the athletic achievements. Although there has been much less attention focused on the effects of intercollegiate sports on the athletes themselves and other students, there appear to be a number of conflicting implications for the intellectual atmosphere and achievements of university students from adopting a big-time sports program and its attendant culture.

What has received virtually no attention is the opportunity cost accompanying any of these possible changes. If athletic success does boost donations and attract more and better credentialed applicants to the successful institutions, from where do the donations and students come, and is the reallocation of these resources efficient and equitable? It is 
impossible to decide if the indirect effects of college athletics are desirable or undesirable by looking at just one side of a reallocation of resources. If a university wants to attract more or different students or to increase donations that support general academic purposes, might the funds currently spent subsidizing intercollegiate athletics be more productive in addressing these goals directly by bolstering the budgets of university development and admissions offices? Up to this point, the net social welfare and equity implications of any indirect effects of college sports on the institutions that host big-time intercollegiate teams really remain unknown. It is possible that these effects could be sufficiently large and undesirable to outweigh the consumers surplus created by the direct entertainment value of intercollegiate athletic competition.

\section{$\underline{\text { References }}$}

Allen, M. (1999). UConn Finds Rich Off-court Gains in Basketball Power. The New York Times on the Web. (March 31), pp. 1-4.

Amato, Louis; Gandar, John M.; Tucker, Irvine B., III and Zuber, Richard A. (1996). "Bowls Versus Playoffs: The Impact of Football Player Graduation Rates in the National Collegiate Athletic Association." Economics of Education Review, 15(2), pp. 187-95.

Amato, Louis, John M. Gandar, and Richard A. Zuber. (2001). "The Impact of Proposition 48 on the Relationship Between Football Success and Football Player Graduation Rates," Journal of Sports Economics 2 (2) May, 101-112.

Associated Press. (2006). "Pickens Sets Record with \$165M Oklahoma State Gift," January 10, http://sports.espn.go.com/ncaa/news/story?id=2286820

Baade, Robert A. and Sundberg, Jeffrey O. (1996). "Fourth Down and Gold to Go? Assessing the Link between Athletics and Alumni Giving." Social Science Quarterly, 77(4), pp. 789-803.

Borland, Melvin V.; Goff, Brian L. and Pulsinelli, Robert W. (1992). "College Athletics: Financial Burden or Boon?" Advances in the Economics of Sport, 1, pp. 215-35.

Brand, Myles. 2009). “APR: Mission Accomplished” NCAA Champion Magazine, Summer, p. 5.

Bremmer, D S and Kesselring, R G. (1993). "The Advertising Effect of University Athletic Success: A Reappraisal of the Evidence," Quarterly Review of Economics and Finance, 33 (4), pp. 409-421. 
Brooker, George and Klastorin, T. D. (1981). "To the Victors Belong the Spoils? College Athletics and Alumni Giving." Social Science Quarterly, 62(4), pp. 744-50.

Clotfelter, Charles. (2003). "Alumni Giving to Elite Private Colleges and Universities." Economics of Education Review. Vol. 22, pp. 109-120.

Clotfelter, Charles. (2010). Big Time: The Reign of Commercial Sports in American Universities. Duke University, unpublished manuscript.

Coates, Dennis and Depken II, Craig O. (2008). "Do College Football Games Pay for Themselves? The Impact of College Football Games on Local Sales Tax Revenue." SSRN Working Paper, http://ssrn.com/abstract=1140271.

Coughlin, Cletus, and Homer Erekson. (1984). "An Examination of Contributions to Support Intercollegiate Athletics," Southern Economic Journal, 51(1), July, pp. 180195.

Dee, Thomas S. (2009). "Stereotype Threat and the Student Athlete," NBER Working Papers 14705, February.

Duderstadt, James. (2000). Intercollegiate Athletics and the American University, (Ann Arbor: University of Michigan Press)

Fizel, John L. and Smaby, Timothy. (2004). "Participation in College Athletics and Academic Performance," J. L. Fizel and R. Fort, Economics of College Sports Westport CT: Praeger, 163-73.

Frank, Robert H. (2004). "Challenging the Myth: A Review of the Links Among College Athletic Success, Student Quality, and Donations," Essay prepared for the Knight Commission on Intercollegiate Athletics, May.

Fulks, D. L. (2008). 2004-06 NCAA Revenue and Expenses of Division I Intercollegiate Athletic Programs Report. (Indianapolis, IN: NCAA).

Getz, Malcolm. (2007). Investing in College: A Guide for the Perplexed, (Harvard University Press, Cambridge MA)

Gillium, Jack, Upton, Jodi, and Berkowitz, Steve. (2010). “Amid Funding Crisis, College Athletics Soak Up Subsidies, Fees.” USA Today (January 13).

Goff, Brian, (2000). "Effects of University Athletics on the University: A Review and Extension of Empirical Assessment," Journal of Sport Management 14(2), April.

Grimes, Paul W. and Chressanthis, George A. (1994). "Alumni Contributions to Academics: The Role of Intercollegiate Sports and NCAA Sanctions. " American Journal of Economics and Sociology, 53(1), pp. 27-40. 
Harrison, William B.; Mitchell, Shannon K. and Peterson, Steven P. (1995). "Alumni Donations and Colleges' Development Expenditures: Does Spending Matter?" Journal of Economics and Sociology, 54(4), pp. 397-412.

Holmes, Jessica A.; Meditz, James A. and Sommers, Paul A. (2008). "Athletics and Alumni Giving." Journal of Sports Economics, 9(5), pp. 538-52.

Humphreys, Brad R. (2006). "The Relationship Between Big-Time College Football and State Appropriations for Higher Education," International Journal of Sport Finance, (1), pp 119-128.

Humphreys, Brad R. and Mondello, Michael. (2009). "Intercollegiate Athletic Success and Donations at NCAA Division I Institutions." Journal of Sports Management.

Knight Commission on Intercollegiate Athletics. (2006). Public Opinion Poll.

Litan, Robert E.; Orszag, Jonathan M. and Orszag, Peter R. (2003). "The Empirical Effects of Collegiate Athletics: An Interim Report," National Collegiate Athletic Association.

Long, James E. and Caudill, Steven B. (1991). "The Impact of Participation in Intercollegiate Athletics on Income and Graduation." Review of Economics and Statistics, 73(3), pp. 525-31.

McCormick, Robert E. and Tinsley, Maurice. (91987). "Athletics Versus Academics? Evidence from SAT Scores." Journal of Political Economy, 95(5), pp. 1103-16. . (1990). "Athletics and Academics: A Model of University Contributions," B. Goff and R. D. Tollison, Sportometrics. College Station, TX: A\&M University Press, 193-204.

McEvoy, Chad. (2005). "The Relationship between Dramatic Changes in Team Performance and Undergraduate Admissions Applications." The Smart Journal, 2(1), pp. 17-24.

Mixon, Franklin G. Jr.; Trevino, L. J. and Minto, T. C. (2004). "Touchdowns and Test Scores: Exploring the Relationship between Athletics and Academics." Applied Economic Letters, 11(7), pp. 421-24.

Monks, James. (2003). "Patterns of Giving to One's Alma Mater Among Young Graduates from Selective Institutions," Economics of Education Review 22(2), April, pp. 121130.

Murphy, Robert G. and Trandell, Gregory A. (1994). "The Relation between a University's Football Record and the Size of Its Applicant Pool." Economics of Education Review, 13(3), pp. 265-70.

National Collegiate Athletic Association. (2009). 2004-2008 NCAA Revenues and Expenses of Division I Intercollegiate Athletics Programs Report (Indianapolis, IN: August). 
Noll, Roger G. (1999) "The Business of College Sports and the High Cost of Winning." Milliken Institute Review, Third Quarter, pp. 24-37.

Osborne, Evan. (2004). "Motivating College Athletes," J. L. Fizel and R. Fort, Economics of College Sports. Westport, CT: Praeger, 51-62.

Pennington, Bill. (2006). "Small Colleges, Short of Men, Embrace Football.” New York Times, July 10.

Pope, Devin G. and Pope, Jaren C. (2009). "The Impact of College Sports Success on the Quantity and Quality of Student Applications," Southern Economic Journal, 75(3), January, pp, 750-780.

Plato, The Republic, Part III. (Indianapolis: Hackett Publishing, 1992) Translated by G.M.A. Grube.

Rather, Dan. (1985). "When the Cheering Stops.” CBS Evening News, October 7.

Rees, Daniel, and Schnepel, Kevin T. (2009). "College Football Games and Crime." Journal of Sports Economics." Vol. 10, No. 1, pp. 68-87.

Reynolds, Gretchen. (2009). "What Sort of Exercise Can Make You Smarter," New York Times Magazine, September 20, p.24.

Rhoads, Thomas A. and Gerking, Shelby. (2000). "Educational Contributions, Academic Quality, and Athletic Success." Contemporary Economic Policy, 18(2), pp. 248-58.

Rishe, Patrick James. (2003). "A Reexamination of How Athletic Success Impacts Graduation Rates." American Journal of Economics and Sociology, 62(2), pp. 40727.

Sacerdote, Bruce. (2001). "Peer Effects with Random Assignment: Results for Dartmouth Roommates." Quarterly Journal of Economics, May, 116(2), pp. 681-704

Sandy, Robert and Sloane, Peter. (2004). "Why Do U.S. Colleges Have Sports Programs?," J. L. Fizel and R. Fort, Economics of College Sports. Westport CT: Praeger, 87-109.

Shulman, James and William G. Bowen. (2001). The Game of Life: College Sports and Educational Values, Princeton University Press.

Siegfried, John J. and Getz, Malcolm. (2002). "Economic Issues in Intercollegiate Athletics: A Book Review Essay." Southern Economic Journal, 68(4), pp. 972-78.

Sigelman, Lee and Carter, Robert. (1979). "Win One for the Giver? Alumni Giving and Big-Time College Sports." Social Science Quarterly, 60(2), pp. 284-94.

Sigelman, Lee and Bookheimer, Samuel. (1983). "Is It Whether You Win or Lose? Monetary Contributions to Big-Time College Athletic Programs." Social Science Quarterly, 64(2), pp. 347-59. 
Sigelman, Lee and Wahlenbeck, Paul J. (1999). "Gender Proportionality in Intercollegiate Athletics: The Mathematics of Title Ix Compliance." Social Science Quarterly, 80(3), pp. 518-38.

Smith, D. Randall. (2008). "Big-Time College Basketball and the Advertising Effect, Does Success Really Matter?" Journal of Sports Economics, 9(4), pp. 387-406.

Suggs, Welch. (2000). "Swarthmore Kicks Football Out of the College," Chronicle of Higher Education, December 15.

Thamel, Pete. (2010). "College Conferences Ponder Expansion, and Their Extinction." New York Times, April 19.

Tierney, Michael. (2009). “Georgia State Hoping Football Builds Community in a Football Town,” New York Times April 19.

Toma, J. Douglas and Cross, Michael E. (1998). "Intercollegiate Athletics and Student College Choice: Exploring the Impact of Championship Seasons on Undergraduate Applications." Research in Higher Education, 39(6), pp. 633-61.

. (2004). "A Reexamination of the Effect of Big-Time Football and Basketball Success on Graduation Rates and Alumni Giving Rates." Economics of Education Review, 23(3), pp. 656-61.

Tucker, Irvine B. (2005). "Big-Time Pigskin Success: Is There an Advertising Effect?" Journal of Sports Economics, 6(2).

Tucker, Irvine B., III and Amato, Louis. (1993). "Does Big-Time Success in Football or Basketball Affect Sat Scores?" Economics of Education Review, 12(2), pp. 177-81.

Turner, Sarah E.; Meserve, Lauren A. and Bowen, William G. (2001). "Winning and Giving: Football Results and Alumni Giving at Selective Private Colleges and Universities." Social Science Quarterly, 82(4), pp. 812-26.

Wolverton, Brad. (2007). "Growth in Sports Gifts May Mean Fewer Academic Donations," Chronicle of Higher Education, October 5. . (2009). "A Powerful League Piles Up Its Advantages," Chronicle of Higher Education, September 4, pp. A-1, A-26, A-27, A-28.

Wunnava, Phanindra V. and Lauze, Michael A. (2001) "Alumni Giving at a Small Liberal Arts College: Evidence from Consistent and Occasional Donors," Economics of Education Review, 20 (6) December, pp 533-43.

Zengerle, Jason. (2010). “Special Report: Compensation.” Business Week, April 5, pp. 5862.

Zimbalist, Andrew. (1999). Unpaid Professionals: Commercialism and Conflict in Bigtime College Sports. Princeton University Press. 
Zimmerman, David J. (2003). "Peer Effects in Academic Outcomes: Evidence from a

Natural Experiment." Review of Economics and Statistics, February, 85(1), pp. 923. 